\title{
Protean Career Orientation and Perceived Employability: The Mediating Role of Career Self-Management
}

\author{
Jasmine Kaur ${ }^{*}$ and Sanjay Kaushik ${ }^{* *}$
}

Abstract

The study examines the relationship between protean career orientation and perceived employability along with the engagement in proactive career behavior. The main objective of this paper is to understand how protean career orientation would form perceptions of student's employability with career self-management as a mediator. Data was collected with the help of a questionnaire from 182 business school students at Panjab University, Chandigarh. The result of correlation analysis indicates that a positive relationship exists between protean career orientation and perceived employability. PROCESS macro given by Hayes has been used to test the mediation. Analysis by bootstrapping method reveals that career self-management fully mediates the relationship between the two variables. Theoretically, this study extends the presence of protean career orientation beyond the work domain into the student life. It also adds on to the cross-cultural research by examining protean career orientation that is a US rooted concept in the Indian scenario. The practical implication of this study is that it improves perception of students towards their employability by indulging in career self-management initiatives. Further, business school management should aim at interventions to increase the self-directed and values-driven nature of students to make them more proactive with regards to their career management.

Keywords: Protean Career Orientation, Career Self-Management, Perceived Employability, Business School Students

\section{INTRODUCTION}

A dynamic and turbulent environment characterizes the current economy with insecurity and uncertainty (Hall, 1996, 2002). Psychological contracts have transformed to a short-term from a long-term arrangement wherein fixed career paths no longer exist and individuals do not see a lifelong career with the same organization (Rousseau, 1995). In response to the new environment, protean career has emerged in the $21^{\text {st }}$ century (Hall, 1996). This new career era necessitates individuals to engage in career management competencies to generate career opportunities that enable them to achieve their career goals and guarantee employability (Hall and Moss, 1998). Protean mindset allows employees to work with numerous organizations in transactional relationships that make them valuable and employable to current and future employers (Fugate, 2006; Rothwell and Arnold, 2007; Vanhercke et al., 2014).

Protean career is the career in which a person is in charge of career development and not the organization (Hall, 1996, 2004). The career path is changed accordingly from time to time to meet the needs of the individual. It

Research Scholar, University Business School, Panjab University, Chandigarh. E-mail: jasminekukreja3@gmail.com (Corresponding Author)

** Dean, College Development Council, Professor, University Business School, Panjab University, Chandigarh.

E-mail: sanjaykaushik@pu.ac.in 
includes a calling towards one's career. It is a hallmark of identity changes and continuous short learning cycles. Protean career orientation implies a mindset, an attitude that reflects self-direction, freedom and value-driven decision making (Briscoe and Hall, 2006). Translation of this orientation into concrete action is done with selfmanagement behaviors (Vos and Soens, 2008).

Career self-management implies proactivity of an individual in managing their careers (Orpen, 1994; Kossek et al., 1998; King, 2004). Two components of career self-management have been recognized, i.e. reflective and behavioral. Reflective component relates to the insights that individuals develop in their career ambitions. Behavioral component indicate the behaviors initiated by employees to manage their careers (Gould and Penley, 1984; Noe, 1996; Sturges et al., 2002). Career self-management in these studies is known by a variety of terms i.e. career strategies, proactive career behavior and career competencies (Sturges et al., 2000, 2002; Kuijpers et al., 2006).

Career self-management initiatives enable individuals to be more aware of their skills, capabilities and form the basis for perceived employability (Jackson and Wilton, 2017). Employability is a critical factor for employees in the job market (Fugate, Kinicki, and Ashforth 2004) and a high level of attention is paid on increasing the employability of students in universities (Yorke, 2004). Employability has been described as the capacity of individuals to retain the jobs they have, or to get the one they desire (Rothwell and Arnold, 2007). The focus of this study is on perceived employability that is an individual's perception of his or her opportunities to obtain or retain jobs (Vanhercke et al., 2014).

Empirical research on protean career orientation is still in its nascent stage. This study answers the call for it and examines whether the protean career concept that is rooted in American culture can be observed in India as well. Majority of the studies on protean career orientation are focused on individuals who are currently employed. The study extends the study of protean career orientation beyond the working population. Understanding the career orientation of the business school students helps in their transition from university to work and future career prospects. Moreover, this paper investigates the proactive career management behaviors initiated by students and their perception of employability.

In order to address the research gaps, the main objective of this paper is to understand how protean career orientation would form perceptions of student's employability with career self-management as a mediator. The objectives of this study are twofold. First, to explore protean career orientation, career self-management and perceived employability among business school students at the university level. Second, to analyze the relationship between protean career orientation and perceived employability with career self-management as a mediator. The present study contributes to the literature in several ways. It undertakes a new approach to protean career orientation by examining it at the student level. Further, it also studies the proactive career behavior that students engage in to enhance their career and prospects of employability. The research question the study intends to address is: Are students with protean orientation more proactive in management of their careers?

\section{CONCEPTUAL BACKGROUND AND HYPOTHESES DEVELOPMENT}

\section{Protean Career Orientation}

Hall (1976) first introduced the concept of protean career. Protean has been compared to the Greek God Proteus who could transform his shape at will. It has been further referred to as "the path with a heart" (Shepard, 1984). The perception of an employee towards protean career has been defined as protean career orientation (Briscoe and Hall, 2006). It does not indicate any particular behavior but it is the career-oriented attitude that represents value- 
based decision-making, autonomy, and self-direction. Hirschi, Jaensch and Herrmann (2017, p.208) described protean career orientation "as an outlook in which the person, not the organization, is in charge of career development."

Briscoe and Hall (2006) identified two dimensions of protean career orientation: values-driven and self-directed career management. Values-driven component reflects the degree to which personal values of an individual impact alternative career decisions. Self-directed component refers to the degree one is independent and takes charge of his or her career. The dual-dimensional aspect of protean career orientation that consists of valuesdriven and self-directed component have been used in various studies (Porter, Woo and Tak, 2016; Direnzo, Greenhaus and Weer, 2015; Rahim and Rohaida, 2015; Volmer and Spurk, 2011; Briscoe and Finkelstein, 2009 and Briscoe, Hall and Muth, 2006). Baruch (2014) introduced the unidimensional aspect of protean career orientation on the assumption that being self-directed with regard to one's values can be viewed as one dimension. For the purpose of this study, the two dimensions of protean career orientation: values-driven and self-directed have been studied.

\section{Career Self-Management}

Career self-management has been defined as the extent to which an individual regularly gathers information, takes initiative in solving career problems and making decisions (Kossek et al.; 1998). It is the proactivity that employees depict in managing their careers (Orpen, 1994; Kossek et al., 1998; King, 2004). It is a type of vocational behavior that employees portray throughout their professional lifetime and not just at the beginning of their careers (King, 2004).

Various dimensions of career self-management have been identified over the years such as creating career opportunities, extending work involvement, opinion conformity, self-nomination, networking, seeking career guidance and other enhancement (Gould and Penley, 1984); individual career planning and individual career tactics (Orpen, 1994); developmental feedback seeking and job mobility preparedness (Kossek et al., 1998) and positioning behavior, influence behavior and boundary management (King, 2004). For the purposes of the study, three dimensions given by Hirschi et al., (2018) namely networking, career exploration and learning have been adopted.

\section{Perceived Employability}

Fugate et al., (2004, p. 23) defined employability as "one's ability to identify and realise career opportunities". Rothwell et al., (2008, p. 2) defined self-perceived employability as "the perceived ability to obtain sustainable employment appropriate to one's qualification level." In today's volatile career climate employability increases the likelihood of individuals obtaining employment and generating career opportunities, and it involves the perception of employees to adapt efficiently to various changes that promote transition among jobs, within and between organizations (Hall and Mirvis, 1995; Fugate et al., 2004; McArdle et al., 2007; Lin, 2015).

Previous studies identified internal and external employability as its dimensions (Rajan, 1997; Kirschenbaum and Mano-Negrin, 1999; Rothwell and Arnold, 2007). The student's perception of employability in this study included- university's reputation (brand strength), belief in self, reputation of one's field of study and state of the external market (Rothwell, Herbert and Rothwell, 2008). 


\section{Protean Career Orientation, Career Self-Management and Perceived Employability}

Protean career orientation has been studied in association with several variables such as organizational commitment, organizational identification, self-efficacy (Baruch, 2014), work-life balance (Direnzo, Greenhaus and Weer, 2015), and work values like altruism, independence and autonomy (Abessolo, Hirschi and Rossier, 2017). It is predicted that individuals who are self-directed would be proactive in managing their careers. Limited studies have examined the relationship between protean career orientation and career self-management. It was found that protean career orientation had a positive relationship with and impact on career self-management (Vos and Soens, 2008; Rahim and Siti-Rohaida, 2015; Direnzo, Greenhaus and Weer, 2015; Herrmann, Hirschi and Baruch, 2015). Thus, the following hypothesis has been formulated:

Hypothesis 1: There exists a significant relationship between protean career orientation and career selfmanagement among business school students.

Career self-management competencies lead to a better understanding of one's self and enables an individual to make informed choices with respect to employment opportunities (Jackson and Wilton, 2017). A positive association has been seen between dimensions of career self-management and perceived employability (Purcell et al., 2013; Qenani, MacDougall and Sexton, 2014; Okay-Somerville and Scholarios, 2015; Jackson and Wilton, 2017). Career management skills are considered to increase the probability of obtaining desired jobs. Hence, the following hypothesis has been formulated:

Hypothesis 2: There exists a significant relationship between career self-management and perceived employability among business school students.

A few studies have examined the relationship between protean career orientation and perceived employability. A positive relationship has been seen between protean career orientation and perceived employability where both the dimensions of protean career orientation had an impact on perceived employability (Voes and Soens, 2008; Lin, 2015; Donald, Baruch and Ashleigh, 2017). Being self-directed and values-driven translates into higher perception of getting a job. Thus, the following hypothesis has been formulated:

Hypothesis 3: There exists a significant relationship between protean career orientation and perceived employability among business school students.

Conflicting results have been seen in the limited studies that examined the relationship between protean career orientation and perceived employability with career self-management as a mediator. Protean career attitude was found to be positively associated with career self-management that had no significant relation with perceived employability (Vos and Soens, 2008). Another study found that learning goal competency fully mediated the relationship between protean career orientation and perceived internal employability, and partially mediated with perceived external employability (Lin, 2015). However, there is a scarcity of studies on the relationship among protean career orientation, career self-management and perceived employability at the student level. Based on the previous studies and the gaps therein, the following hypothesis has been formulated:

Hypothesis 4: Career self-management mediates the relationship between protean career orientation and perceived employability among business school students. 


\section{Demographics and Protean Career Orientation}

Protean careers have been found to be more accommodating of the women's career path as it leads to a better worklife balance (Reitman and Schneer, 2003). In the same study, it was found that younger employees preferred protean careers. With respect to gender, protean career orientation was found to be more prevalent among the women (McDonald, Brown and Bradley, 2005). In support of this, another study stated that women were more values-driven whereas in terms of self-directed component, no gender differences were seen. Moreover with increasing age, employees were found to be less self-directed and more values-driven (Segers, 2008). In contrast to the above studies, no significant difference was found in protean career orientation with respect to gender and age (Hirschi, Jaensch, and Herrmann, 2017). Based on the above studies, the following hypotheses have been formulated:

Hypothesis 5a: There exists a significant difference in protean career orientation with regard to age among business school students.

Hypothesis 5b: There exists a significant difference in protean career orientation with regard to gender among business school students.

Hypothesis 5c: There exists a significant difference in protean career orientation with regard to marital status among business school students.

Hypothesis $5 d$ : There exists a significant difference in protean career orientation with regard to stream among business school students.

Hypothesis 5e: There exists a significant difference in protean career orientation with regard to specialization among business school students.

Hypothesis 5f: There exists a significant difference in protean career orientation with regard to work experience among business school students.

\section{RESEARCH METHODOLOGY}

\section{Participants}

The universe for this research consisted of all the business school students at Punjab University. Students from the various streams: MBA (General, International Business, Human Resources, Entrepreneurship, and Executive), M.Com (Hons.) and Ph.D. were the target population. A total of 250 questionnaires were distributed, out of which 182 completed questionnaires were returned. So, the response rate was $72.8 \%$ and 182 students formed a part of this study's usable sample. Table 1 presents the demographic profile of the respondents. The sample consists of 55.5 percent of males, with majority of them less than 25 years of age ( 70.3 percent) and unmarried ( 92.3 percent). 
Table 1. Demographic Profile of the Respondents

\begin{tabular}{|c|c|c|c|}
\hline & & Number & Percentage \\
\hline \multirow[t]{3}{*}{ Age } & Less than 25 years & 128 & 70.3 \\
\hline & $25-30$ years & 49 & 26.9 \\
\hline & 30 years and above & 5 & 2.7 \\
\hline \multirow[t]{2}{*}{ Gender } & Male & 101 & 55.5 \\
\hline & Female & 81 & 44.5 \\
\hline \multirow[t]{2}{*}{ Marital Status } & Married & 14 & 7.7 \\
\hline & Unmarried & 168 & 92.3 \\
\hline \multirow[t]{7}{*}{ Stream } & MBA (General) & 47 & 25.8 \\
\hline & MBA (IB) & 44 & 24.2 \\
\hline & MBA (HR) & 14 & 7.7 \\
\hline & MBA (Entrepreneurship) & 8 & 4.4 \\
\hline & MBA (Executive) & 16 & 8.8 \\
\hline & M.Com (Hons.) & 27 & 14.8 \\
\hline & Ph.D. & 26 & 14.3 \\
\hline \multirow[t]{7}{*}{ Specialization } & Finance & 28 & 15.4 \\
\hline & Marketing & 30 & 16.5 \\
\hline & Human Resource Management & 21 & 11.5 \\
\hline & International Business & 44 & 24.2 \\
\hline & Entrepreneurship and Strategic & 12 & 6.6 \\
\hline & Management & & \\
\hline & None & 47 & 25.8 \\
\hline \multirow[t]{2}{*}{ Work Experience } & With & 67 & 36.8 \\
\hline & Without & 115 & 63.2 \\
\hline
\end{tabular}

\section{Measures}

The data was collected through self-administered questionnaires using the following measures:

\section{Protean Career Orientation}

Protean career orientation was adapted using the fourteen items scale given by Briscoe et al., (2006) on a 5-point 
Likert scale ranging from 1 (to little or no extent) to 5 (to a great extent). The scale comprised of two dimensions: self-directed and values-driven. Wordings of the items were adjusted to reflect student's perspective. Sample items included "I am in charge of my own career" and "What is most important to me is how I feel about my career success, not how other people feel about it."

\section{Career Self-Management}

Career self-management was assessed using the nine items scale developed by Hirschi et al., (2018). The respondents rated the items on a 5-point Likert scale from 1 (not true at all) to 5 (completely true). The scale consisted of three dimensions- networking, career exploration and learning. Sample items included "I frequently build contacts with other people who are important for my career development" and "I make sure that my workrelated abilities and knowledge are up-to-date."

\section{Perceived Employability}

Perceived employability was measured using the sixteen items scale constructed by Rothwell, Herbert, and Rothwell (2008) on a 5-point Likert scale from 1 (strongly disagree) to 5 (strongly agree). Sample items included "I am generally confident of success in job interviews and selection events" and "Employers specifically target this university in order to recruit individuals from my subject area(s)."

\section{Reliability of the Instruments and Proposed Model of the Study}

The reliability of the scales used in the study was examined with Cronbach's alpha so as to measure its internal consistency. The reliability estimates denoted by alpha ranged from .75 to .89 as given in Table 2 . Reliability estimates of .70 and above indicate strong reliability of the scales. Hence, the scales used in the study were consistent and reliable. The proposed model of the study is given in Figure 1.

Table 2. Reliability Coefficients

\begin{tabular}{lccc}
\hline Variables & Cronbach's Alpha & Mean & No. Of Items \\
\hline Protean Career Orientation & .755 & 4.055 & 14 \\
Career Self-Management & .868 & 3.806 & 9 \\
Perceived Employability & .891 & 3.703 & 16 \\
\hline
\end{tabular}




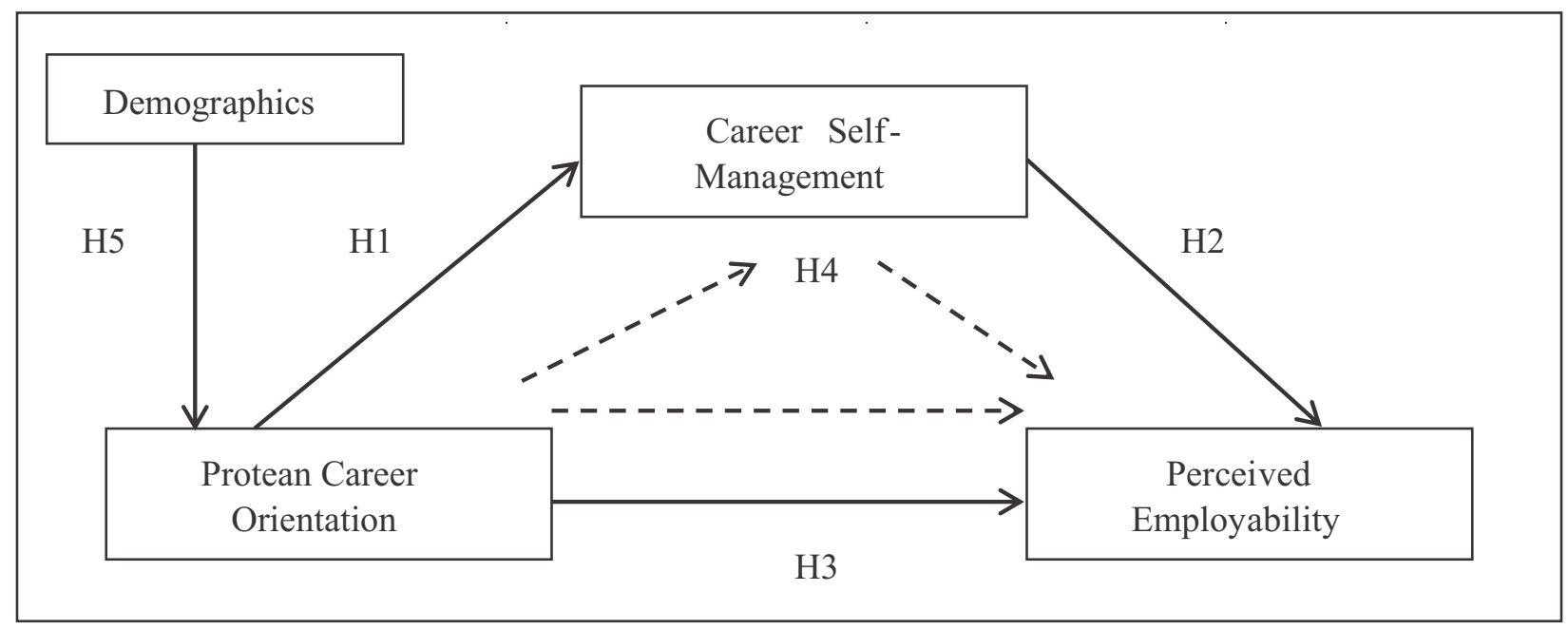

Figure 1. Proposed Model of the Studys

\section{Data Analyses}

Correlation analysis was employed to examine the relationship among protean career orientation, career selfmanagement and perceived employability. The mediation effect of career self-management was tested using Hayes' PROCESS macro (2017). Further, ANOVA and independent samples t-test were used to test the significant difference in protean career orientation with regard to demographics.

\section{Interpretation of the Findings}

Pearson's product moment coefficient of correlation was used to examine the relationship between protean career orientation and career self-management, the results of which are given in Table 3 . The results reveal that a significant positive relationship exists between protean career orientation and career self-management among business school students, $\mathrm{r}(180)=.42, \mathrm{p}<.01$. Thus, $\mathbf{H 1}$ is accepted.

To study the relationship between career self-management and perceived employability, Pearson's product moment coefficient of correlation was applied. The results in Table 3 indicate that a significant positive relationship exists between career self-management and perceived employability among business school students, $\mathrm{r}(180)=.581, \mathrm{p}<.01$. Thus, $\mathbf{H} 2$ is accepted.

To examine the relationship between protean career orientation and perceived employability, Pearson's product moment coefficient of correlation was used. The results as given in Table 3 show that a significant positive relationship exists between protean career orientation and perceived employability among business school students, $\mathrm{r}(180)=.351, \mathrm{p}<.01$. Thus, $\mathbf{H 3}$ is accepted. 
Table 3: Means, Standard Deviations and Correlations for all the Variables

\begin{tabular}{llllll}
\hline Variable & $\boldsymbol{M}$ & $\boldsymbol{S D}$ & $\mathbf{1 .}$ & $\mathbf{2 .}$ & $\mathbf{3 .}$ \\
\hline $\begin{array}{l}\text { 1. Protean Career } \\
\text { Orientation }\end{array}$ & 4.0546 & .55840 & & & \\
$\begin{array}{l}\text { 2. Career Self- } \\
\text { Management }\end{array}$ & 3.8065 & .42090 & $.420^{* *}$ & & \\
$\begin{array}{l}\text { 3. Perceived } \\
\text { Employability }\end{array}$ & 3.7030 & .59503 & $.351^{* *}$ & $.581^{* *}$ & \\
\hline
\end{tabular}

Note: $\mathrm{n}=182 .{ }^{* *}$. Correlation is significant at 0.01 level (2-tailed).

PROCESS Macro (Hayes, 2017) was used to explore the mediation effect of career self-management on the relationship between protean career orientation and perceived employability. In PROCESS Macro version 3.5, model 4 was used to test the hypothesis and the results are given in Table 4 . The results revealed that there was a significant positive effect of protean career orientation on career self-management $(\mathrm{B}=.593, \mathrm{SE}=.096, \mathrm{p}=.000)$. On regressing perceived employability on protean career orientation and career self-management, it was seen that there was a significant positive effect of career self-management on perceived employability $(\mathrm{B}=.494, \mathrm{SE}=.062$, $\mathrm{p}=.000)$. The total effect of protean career orientation on perceived employability was also found to be significant $(\mathrm{B}=.466, \mathrm{SE}=.093, \mathrm{p}=.000)$. The direct effect of protean career orientation on perceived employability was found to be insignificant $(\mathrm{B}=.1725, \mathrm{SE}=.088, \mathrm{p}>.05)$. As the value of protean career orientation becomes insignificant after controlling for career self-management, results support for full mediation. Lastly, indirect effect was tested using bootstrapping method. At $95 \%$ confidence interval, 5000 bias-corrected bootstrap samples were utilized. The results shown in Table 5 depicts that a significant indirect effect of protean career orientation on perceived employability exists through career self-management as zero does not fall within the confidence interval (indirect effect $=.2930, \mathrm{SE}=.068,95 \% \mathrm{CI}=.1716, .4360$ ). The indirect effect was confirmed with the Sobel test $(\mathrm{z}=4.886, \mathrm{SE}=.060, \mathrm{p}=.000)$. Therefore, $\mathbf{H 4}$ is accepted where career selfmanagement fully mediates the relationship between protean career orientation and perceived employability among business school students.

Table 4: Mediation Analysis

\begin{tabular}{lccccccc}
\hline Variables & $\mathrm{B}$ & $\mathrm{SE}$ & $\mathrm{t}$ & $\mathrm{p}$ & $\mathrm{LLCI}$ & $\mathrm{ULCI}$ & $\mathrm{R}^{2}$ \\
\hline $\mathrm{PCO} \rightarrow \mathrm{CSM}$ & .5931 & .0957 & 6.2002 & $.0000^{* *}$ & .4043 & .7818 & .1760 \\
$\mathrm{CSM} \rightarrow \mathrm{PE}$ & .4940 & .0622 & 7.9391 & $.0000^{* *}$ & .3712 & .6168 & .3515 \\
$\mathrm{PCO} \rightarrow \mathrm{PE}$ & .4655 & .0926 & 5.0273 & $.0000^{* *}$ & .2828 & .6482 & .1231 \\
(Total Effect) & & & & & & & \\
PCO $\rightarrow$ PE & .1725 & .0880 & 1.9613 & .0514 & -.0011 & .3461 & \\
(Direct Effect) & & & & & & &
\end{tabular}

Note: $\mathrm{n}=182$. PCO, Protean Career Orientation; CSM, Career Self-Management; PE, Perceived Employability; 
B, Unstandardized regression coefficient; LLCI, Lower Level Confidence Interval; ULCI, Upper Level Confidence Interval. **. Significant at .01 level.

Table 5: Indirect Effect of Protean Career Orientation on Perceived Employability

\begin{tabular}{lcccc}
\hline Variable & Effect & SE (boot) & \multicolumn{2}{c}{ Bootstrap 95\% Confidence Interval } \\
\cline { 3 - 5 } & & & LL & UL \\
\hline Career Self -Management & .2930 & .0681 & .1716 & .4360 \\
\hline
\end{tabular}

Note: $\mathrm{n}=182$, Bootstrap sample size $=5000, \mathrm{LL}=$ Lower Level, $\mathrm{UL}=$ Upper Level

The difference in protean career orientation with regard to demographics was analyzed with the use of independent samples t-test and ANOVA. To test if significant difference exists in protean career orientation with regard to age among business school students, ANOVA was employed. The results as given in Table 6 depict that no significant difference exists in protean career orientation with regard to age among business school students, $\mathrm{F}$ $(2,179)=.429, \mathrm{p}>.05$. Thus, $\mathbf{H 5 a}$ is rejected .

To test if significant difference exists in protean career orientation with regard to gender among business school students, independent samples t-test was applied. The results as given in Table 6 reveal that no significant difference exists in protean career orientation with regard to gender among business school students, $\mathrm{t}(180)=$ $1.016, \mathrm{p}>.05$. Thus, $\mathbf{H 5 b}$ is rejected.

To test if significant difference exists in protean career orientation with regard to marital status among business school students, independent samples t-test was applied. The results as given in Table 6 reveal that no significant difference exists in protean career orientation with regard to marital status among business school students, $\mathrm{t}(180)$ $=-.882, \mathrm{p}>.05$. Thus, $\mathbf{H 5} \mathbf{c}$ is rejected.

To test if significant difference exists in protean career orientation with regard to stream among business school students, ANOVA was employed. The results as given in Table 6 depict that significant difference exists in protean career orientation with regard to stream among business school students, $\mathrm{F}(6,175)=2.519, \mathrm{p}<.05$. Business school students from the $\mathrm{Ph} . \mathrm{D}$. stream have the highest level of protean career orientation and differ significantly from the MBA(Executive) stream. Thus, H5d is accepted.

To test if significant difference exists in protean career orientation with regard to specialization among business school students, ANOVA was employed. The results as given in Table 6 depict that no significant difference exists in protean career orientation with regard to specialization among business school students, $F(5,176)=1.663$, $p>$ .05. Thus, H5e is rejected.

To test if significant difference exists in protean career orientation with regard to work experience among business school students, independent samples t-test was applied. The results as given in Table 6 reveal that significant difference exists in protean career orientation with regard to work experience among business school students, $t$ $(180)=2.102, \mathrm{p}<.05$. Business school students with work experience had a higher level of protean career orientation Thus, H5f is accepted. 
Table 6: Difference in Protean Career Orientation with regard to Demographics

\begin{tabular}{|c|c|c|c|c|c|c|}
\hline & & $\mathbf{N}$ & Mean & S.D. & $\begin{array}{l}\text { Test } \\
\text { Statistic }\end{array}$ & Sig. \\
\hline \multirow[t]{3}{*}{ Age } & Less than 25 years & 128 & 4.0569 & .41080 & \multirow{3}{*}{.429} & \multirow{3}{*}{.652} \\
\hline & $25-30$ years & 49 & 4.0321 & .44441 & & \\
\hline & 30 years and above & 5 & 4.2143 & .50000 & & \\
\hline \multirow[t]{2}{*}{ Gender } & Male & 101 & 4.0262 & .43008 & \multirow[b]{2}{*}{-1.016} & \multirow[b]{2}{*}{.311} \\
\hline & Female & 81 & 4.0899 & .40905 & & \\
\hline \multirow[t]{2}{*}{ Marital Status } & Married & 14 & 3.9592 & .50795 & \multirow[b]{2}{*}{-.882} & \multirow[b]{2}{*}{.379} \\
\hline & Unmarried & 168 & 4.0625 & .41364 & & \\
\hline \multirow[t]{7}{*}{ Stream } & MBA (General) & 47 & 4.0897 & .36890 & \multirow{7}{*}{2.519} & \multirow{7}{*}{$.023 *$} \\
\hline & MBA (IB) & 44 & 4.0097 & .43696 & & \\
\hline & MBA (HR) & 14 & 3.9949 & .37532 & & \\
\hline & $\begin{array}{l}\text { MBA } \\
\text { (Entrepreneurship) }\end{array}$ & 8 & 3.9821 & .55163 & & \\
\hline & MBA (Executive) & 16 & 3.8795 & .45529 & & \\
\hline & M.Com (Hons .) & 27 & 3.9788 & .38251 & & \\
\hline & Ph.D. & 26 & 4.3077 & .40847 & & \\
\hline \multirow[t]{6}{*}{ Specialization } & Finance & 28 & 4.0638 & .37209 & \multirow{6}{*}{1.663} & \multirow{6}{*}{.146} \\
\hline & Marketing & 30 & 4.2214 & .30150 & & \\
\hline & $\begin{array}{l}\text { Human Resource } \\
\text { Management }\end{array}$ & 21 & 4.1224 & .45856 & & \\
\hline & $\begin{array}{l}\text { International } \\
\text { Business }\end{array}$ & 44 & 4.0097 & .43696 & & \\
\hline & $\begin{array}{l}\text { Entrepreneurship } \\
\text { and Strategic } \\
\text { Management }\end{array}$ & 12 & 4.0298 & .56116 & & \\
\hline & None & 47 & 3.9605 & .42645 & & \\
\hline \multirow{2}{*}{$\begin{array}{l}\text { Work } \\
\text { Experience }\end{array}$} & With & 67 & 4.1397 & .46030 & \multirow[b]{2}{*}{2.102} & \multirow[b]{2}{*}{$.037^{*}$} \\
\hline & Without & 115 & 4.0050 & .38971 & & \\
\hline
\end{tabular}

* Significant at .05 level 


\section{DISCUSSION OF THE STUDY}

The aims of the study were to investigate the presence of protean career orientation, career self-management and perceived employability among the university business school students. The results reveal that protean career orientation was associated with career self-management, which in turn related to perceived employability. The positive relation between protean career orientation and career self-management is in line with the previous studies and supports that individuals with protean career orientation strive for concrete actions to manage their career (Hall, 2004; Vos and Soens, 2008; Direnzo, Greenhaus and Weer, 2015). It indicates that individuals with protean career orientation identify and direct their own career path.

Career self-management was positively related to perceived employability as indicated in the previous studies (Vos and Soens, 2008; Lin, 2015; Donald Baruch and Ashleigh, 2017). The degree to which business school students are proactive in management of their career automatically translates into stronger perceptions of employability. Further, career self-management mediated the relationship between protean career orientation and perceived employability. Business school students who were self-directed and value driven in their approach towards career engaged in career management activities that increased their employability prospects in the future.

The difference in protean career orientation with respect to demographics was also studied. No significant difference was seen in protean career orientation with respect to gender and age, contrary to the previous findings (Reitman and Schneer, 2003; McDonald, Brown and Bradley, 2005; Segers, 2008). It was found that students of the $\mathrm{Ph}$.D. stream and those who had prior work experience were more protean career oriented. No previous study has examined protean career orientation among Ph.D. students but its presence can be attributed to the fact that doctoral study requires self-direction which made the students more proactive and led to the development of protean career orientation. Some of the students pursuing Ph.D. also had work experience. This supports the finding of a qualitative study wherein it was seen that work experience leads to experiential learning. It further enables individuals to recognize career trajectory against their own values and thus, shape protean career orientation (Sargent and Domberger, 2007). In another study it was seen that job experience leads to a greater degree of self-direction (Sergers, 2008).

\section{IMPLICATIONS OF THE STUDY}

\section{Theoretical Implications}

This study has made a number of significant contributions to the career literature. Firstly, the results extend the presence of protean career orientation beyond the work domain into the student life. It recognized the presence of protean career orientation among business school students who were discovered to be self-directed and valuesdriven. This study also adds on to the cross-cultural research by examining protean career orientation that is a US rooted concept in the Indian scenario.

Secondly, this study improves understanding of the perception of employability among students. Discovering the student's perspective of employability is essential as their opinions are not well recognized in the previous studies and developing an understanding of the student's view have a strategic impact on their future employability prospects, performance in an organization and their career success.

Lastly, very few studies had analyzed the empirical linkages among protean career orientation, career self- 
management and perceived employability. This study filled that research void and advanced the theory on it. It found protean career orientation to be predictive of career self-management and perceived employability where career self-management acted as a mediator.

\section{Practical Implications}

The findings of this study have practical implications for both the students and the management of the business school. For students, it recognizes the importance of adopting a self-directed and value-driven approach to manage their careers. Students with a strong protean career orientation had a proactive stance towards their career. Therefore, the business school management should contribute to the development of protean career orientation. Educational institutes can enable students in this by encouraging them to be more proactive and understanding of their values. This can be done through a combination of career counseling, role modeling and experience of work in an organizational environment through internships.

\section{CONCLUSION, LIMITATIONS AND DIRECTIONS FOR FUTURE RESEARCH}

Previous researchers examined the relationship of protean career orientation with other variables, but its association with career self-management and perceived employability among students had remained unexplored. So, this study attempted to fill that gap. Protean career orientation accounted for $17.6 \%$ variability in career selfmanagement and $12.3 \%$ variability in perceived employability. Both protean career orientation and career selfmanagement explained $35.2 \%$ variation in perceived employability. It made a significant contribution by identifying that the university students who are self-directed and values-driven are proactive in managing their career and perceive them to be employable in the future. Protean career orientation enhances engagement in career-management initiative and boosts self-perception of employability. The university should formulate strategies to encourage students to explore career options, engage in networking and continuously learn workrelated skills.

The study is constrained by a few limitations. Firstly, self-reported measures of the variables have been used for this research. To eliminate common method bias, future studies should consider collecting data from various sources. Secondly, data was collected at a single point in time. Further, the study assesses the students' perception of employability. To ascertain whether these perceptions translate into reality, longitudinal study would be useful. This will help in studying the causality among the variables. Lastly, the study was limited to business school students only. Future researchers should test this model with students from different subject areas and universities.

\section{REFERENCES}

Abesollo, M., Hirschi, A., and Rossier, J. (2017). Work values underlying protean and boundaryless career orientations. Career Development International, 22(3), 241-259.

Baruch, Y. (2014). The development and validation of a measure for protean career orientation. The International Journal of Human Resource Management, 25(19), 2702-2723.

Briscoe, J. P., and Finkelstein, L. M. (2009). The "new career" and organizational commitment: Do boundaryless and protean attitudes make a difference?. Career Development International, 14, 242-260.

Briscoe, J. P., Hall, D. T., and DeMuth, R. L. F. (2006). Protean and boundaryless careers: An empirical exploration. Journal of Vocational Behavior, 69, 30-47.

Direnzo, M. S., Greenhaus, J. H., and Weer, C. H. (2015). Relationship between protean career orientation and work-life balance: A resource perspective. Journal of Organizational Behavior, 36, 538-560. 
Donald, W.E, Baruch, Y., and Ashleigh, M. (2019). The undergraduate self-perception of employability: human capital, careers advice, and career ownership. Studies in Higher Education, 44(4), 599-614.

Fugate, M. (2006), "New perspectives on employability" in Greehaus, J. and Callan, G.(Eds),Encyclopedia of Career Development, Sage, Thousand Oaks, CA, 267-70.

Fugate, M., A. J. Kinicki, and B. E. Ashforth. (2004). Employability: A Psycho-social Construct, Its Dimensions, and Applications. Journal of Vocational Behavior, 65 (1), 14-38.

Gould, S., \& Penley, L. E. (1984). Career strategies and salary progression: A study of their relationship in a municipal bureaucracy. Organizational Behavior and Human Performance, 34, 244-265.

Hall, D. T. (2002). Careers in and out of organizations. Thousand Oaks, CA: Sage Publications.

Hall, D.T. (1996). Protean Careers of the 21 st Century. Academy of Management Executive, 10, 8-16.

Hall, D.T. (2004). The Protean Career: A Quarter-Century Journey. Journal of Vocational Behavior, 65(1), 1-13.

Hall, D.T., and Moss, J.E. (1998). The new protean career contract: Helping organizations and employees adapt. Organizational Dynamics, 26(3), 22-37.

Hall, D., and Mirvis, P. (1995). The New Career Contract: Developing the Whole Person at Midlife and Beyond. Journal of Vocational Behavior, 47, 269-289.

Hayes, A.F. (2017). Introduction to Mediation, Moderation and Conditional Process Analysis: A Regression Based Approach. Second Edition. New York: Guilford Publications.

Herrmann, A., Hirschi, A., and Baruch, Y. (2015). The protean career orientation as predictor of career outcomes: Evaluation of incremental validity and mediation effects. Journal of Vocational Behavior, 88, 205-214.

Hirschi, A., Jaensch, V.K., and Herrmann, A. (2017). Protean career orientation, vocational identity, and selfefficacy: an empirical clarification of their relationship. European Journal of Work and Organizational Psychology, 26(2), 208-220.

Hirschi, A., Nagy, N., Baumeler, F., Johnston, C. S., \& Spurk, D. (2018). Assessing Key Predictors of Career Success: Development and Validation of the Career Resources Questionnaire. Journal of Career Assessment, 26(2), 338-358.

Jackson, D., \& Wilton, N. (2017). Perceived employability among undergraduates and the importance of career self-management, work experience and individual characteristics. Higher Education Research \& Development, 36(4), 747-762.

King, Z. (2004). Career self-management: Its nature, causes and consequences. Journal of Vocational Behavior, $65,112-133$.

Kirschenbaum, A., and Mano-Negrin, R. (1999). Underlying labour market dimensions of 'opportunities': The case of employee turnover. Human Relations, 52(10), 1233-1255.

Kossek, E. E., Roberts, K., Fisher, S., and Demarr, B. (1998). Career self-management: A quasi experimental assessment of the effects of a training intervention. Personnel Psychology, 51, 935-962.

Kuijpers, M. A. C. T., Schyns, B., \& Scheerens, J. (2006). Career competencies for career success. The Career Development Quarterly, 55, 168-178.

Lin, Y. (2015). Are you a protean talent? The influence of protean career attitude, learning-goal orientation and perceived internal and external employability. Career Development International, 20(7), 753-772.

McArdle, S., Waters, L., Briscoe, J.P. and Hall, D.T. (2007). Employability during unemployment: Adapatbility, career identify and human and social capital. Journal of Vocational Behavior, 71(2), 247-264.

McDonald, P.K., Brown, K. A., and Bradley, L.M. (2005). Have traditional career paths given way to protean ones? : evidence from senior managers in the Australian public sector. Career Development International, 10(2), 109-129.

Noe, R. (1996). Is career management related to employee development and performance?. Journal of Organizational Behavior, 17, 119-133.

Okay-Somerville, B.; Scholarios, D. (2015) Career Self-Management, Perceived Employability, and Employment Success during University-to-Work Transitions: A Social Cognitive Career Theory 
Perspective. Human Resource Management /Zarzadzanie Zasobami Ludzkimi, 107(6), 33-60.

Orpen, C. (1994). The effects of organizational and individual career management on career success. International Journal of Manpower, 15(1), 27-37.

Porter, C., Woo, S.E., and Tak, J. (2016). Developing and Validating Short Form Protean and Boundaryless Career Attitudes Scales. Journal of Career Assessment, 24(1), 162-181.

Purcell, K., Elias, P., Atfield, G., Behle, H., Ellison, R. and Luchinskaya, D. (2013). Transitions into employment, further study and other outcomes. Warwick Institute of Employment Research, Warwick, UK.

Qenani, E.,Macdougall, N., and Sexton, C. (2014). An empirical study of self-perceived employability: Improving the prospects for student employment success in an uncertain environment. Active Learning in Higher Education, 15, 199-213.

Rahim, N.B. and Siti-Rohaida, M.Z. (2015). Career satisfaction and psychological well-being among professional engineers in Malaysia: The effect of career goal development, Asian Academy of Management Journal, 20(2), 127-146.

Rajan, A. (1997). Employability in the finance sector: Rhetoric vs. Reality. Human Resource Management Journal, 7(1), 67-78.

Reitman, F. and Schneer, J. A. (2003). The promised path: A longitudinal study of managerial careers. Journal of Managerial Psychology, 18(1), 60-75.

Rothwell, A., and J. Arnold. (2007). Self-perceived Employability: Development and Validation of a Scale. Personnel Review, 36(1), 23-41.

Rothwell, A., Herbert, I., and Rothwell, F. (2008). Self-perceived employability: Construction and initial validation of a scale for university students. Journal of Vocational Behavior, 73, 1-12.

Rousseau, D. M. (1995). Psychological contracts in organizations. Thousand Oaks, CA: Sage.

Sargent, L. D., \& Domberger, S. R. (2007). Exploring the development of a protean career orientation: values and image violations. Career Development International, 12(6), 545-564.

Segers, J., Inceoglu, I., Vloeberghs, D., Bartram, D., \& Henderickx, E. (2008). Protean and boundaryless careers: A study on potential motivators. Journal of Vocational Behavior, 73(2), 212-230.

Shepard, H. A. (1984). On the realization of human potential: A path with a heart. In M. B. Arthur, L. Bailyn, D. J. Levenson, \& H. A. Shepard (Eds.), Working with careers (pp. 25-46). New York: Columbia University School of Business.

Sturges, J., Guest, D., \& Mackenzie Davey, K. (2000). Who's in charge? Graduates' attitudes to and experiences of career management and their relationship with organizational commitment. European Journal of Work and Organizational Psychology, 9(3), 351-371.

Sturges, J., Guest, D., Conway, N., \& Mackenzie Davey, K. (2002). A longitudinal study of the relationship between career management and organizational commitment among graduates in the first ten years at work. Journal of Organizational Behavior, 23, 731-748.

Vanhercke, D., De Cuyper, N., Peeters, E., and De Witte, H. (2014). Defining perceived employability: A psychological approach. Personnel Review, 43 (4), 592-605.

Volmer, J., and Spurk, D. (2010). Protean and boundaryless career attitudes: Relationships with subjective and objective career success. Journal for Labour Market Research, 43, 207-218.

Vos, A. D., and Soens, N. (2008). Protean attitude and career success: The mediating role of self-management. Journal of Vocational Behavior, 73, 449-456.

Yorke, M. (2004). Employability in Higher Education: What It Is - and What It Is Not. York: Higher Education Academy. 
